\title{
Fuel Wood Exploitation and Sustainable Forest Management
}

\author{
1*ABANIKANNDA, JO; ${ }^{2}$ DANTANI, A \\ Department of Forestry and Wildlife Management, Bayero University, Kano, Kano state-Nigeria \\ *Corresponding Author Email: abanikay@gmail.com; Tel: +234-7067958815 \\ Co-author Email: dantaniabdulmalik@gmail.com
}

\begin{abstract}
Fuel utilization and cooking, are indispensable parts of human livelihood. Nigeria is a developing nation where the majority depends on cheap and affordable sources of fuel for domestic and commercial cooking. Wood fuel is preferred by most rural people and many urban dwellers during festivals and ceremonies and special preparations. It is mostly preferred because of its cheapness and availability, compared with conventional fuels. The use of wood fuel for cooking has resulted in large scale deforestation, environmental degradation, loss of biodiversity, climatic problems and natural disasters. There is little awareness on the need for sustainable utilization of these important resources through effective planning and management, effective policies and legislations. This review seeks to bridge the gap between forest sustainability and economic development, and the prospects of harnessing alternative sources of renewable energy into developmental programs, as well as the need for abatement and mitigation against forest degradation and habitat loss. The paper relied mainly on secondary information from both empirical and non-empirical researches.
\end{abstract}

DOI:https://dx.doi.org/10.4314/jasem.v25i6.16

Copyright: Copyright (C) 2021 Abanikannda and Dantani. This is an open access article distributed under the Creative Commons Attribution License (CCL), which permits unrestricted use, distribution, and reproduction in any medium, provided the original work is properly cited.

Dates: Received: 20 March 2021; Revised: 27 April 2021; Accepted: 07 May 2021

Keywords: Fuel wood, livelihood, deforestation, degradation, sustainability

Fuel wood refers to the source of energy derived by burning wood materials like logs and twigs and is common among the rural dwellers. It is a traditional source of energy, which has remained the major source of fuel for over half of the world's population (Ogunsanwo and Ajala, 2002). Fuel wood, charcoal, animal dung and sawdust are all biomass products (Sambo, 2009). Most households in the developing countries lack access to modern energy types; therefore they rely on the use of traditional biomass fuels like crop waste, dung, and wood to meet their basic energy needs, especially for cooking. This statement was emphasized in the 2005 UNDP's Millennium Development Goals (MDGs) assessment report. The MDGs are sets of time-bound and measurable goals and targets for combating poverty, hunger, illiteracy, gender inequality, disease, and environmental degradation in the world (specifically the developing countries) by 2015 (UNDP, 2005). The 2011 UNDP assessment of the MDGs has included Nigeria among those countries requiring further effort to improve their energy situation. Anozie et al., (2007) highlighted some of the efforts of the Nigerian government through its Energy Commission and the numerous other research contributions in addressing the energy situation. They concluded that the majority of the energy targets set by the government remained unmet, due to lack of policy implementation, general lack of awareness from consumers of the compelling need to conserve energy and lack of logistics and proper funding. All the four impediments to the improvement of the energy situation in Nigeria described by Anozie et al., (2007) focused on the laxity of the policy makers in either not funding the sectors efficiently or not policing the laws that would regulate the proper use of energy in the country. It is against this background that it is appropriate to provide an academic assessment of the salient issues in the Nigerian energy situation with particular emphasis on the traditional energy (fuel wood) situation, as wood is the major source of cooking energy for the households. Sustainable forest management is a kind of management which ensures a striking balance between ecology, social, cultural and economic activities, it is said to be achieved when rural livelihood is safeguarded, ensuring conservation and protection of biodiversity and ecosystem services provided by the forests, reducing rural poverty and mitigating some of the effects of climate change (LEDS GP, 2016). Sustainable forest management is very important for food security, health and wellbeing of the forests, supply of good quality fresh water, protection against natural hazards such as flood, soil erosion, and protection of soil water and for combating desertification. Forest provides employment and income for the teaming population. consequences of unsustainable forest management is centered towards many problems as follows: Desertification: this refers 
to the land degradation occurring in arid and semiarid regions and dry sub-humid regions resulting from different factors such as climate variability and human activities in an attempt to exploit forest resources for livelihood, where this occur there will be fast decline in forest vegetation and resulting to desertification (UNCCD, 2004). Desertification affects a lot of issues ranging from food producing capacity as more arable lands are affected leading to low productivity for instance, in Nigeria semiarid region is by its nature and characteristics prone to desertification (Aminu, 2003) the zone is prone to climate and human pressure arising from rapidly increasing population and intensive economic activities. The zone constituted the largest livestock zone and grain producing area in the country but prone to desertification (Bzugu and Ibrahim, 2011). Depletion of soil fertility occur as a result of reduction in forest cover, making soil poor in plant nutrients, food production is equally affected because it is dependent on soil fertility, though maintenance of forest cover tends to improve and maintain soil fertility hence resulting to increase in yield production. Soil improvement by trees occur in many forms most important is soil organic matter, nitrogen fixation, nitrogen cycling and augmentation of nutrients uptake (Gajic et al., 2018) the supply usually arise from the above ground litter and pruning deposits and equally the shedding of fine roots. Some tree species harbor bacteria important in fixing nitrogen from the atmosphere thereby enriching the soil (Aminu, 2003). Soil erosion is one of the consequences of unsustainable forest management and equally a threat to food security, this led to removal of top soil where nutrients for plant growth and developments are concentrated leading to disruption of food production. Trees conserve soil by protecting it from direct impact of rainfall and wind thereby reducing erosion to minimum, tree cover also shield the soil against heavy downpour the leaves slowly drops water on the soil given time to seep underground bringing nourishment to animals and plant lives beneath the trees (Aju, 2014). Trees also serves as wind break and shelter belts helping in reducing wind velocity thereby making it insufficient to move soil particles. Economic progress and human well-being are dependent on healthy forest ecosystems, which provide shelter, food, jobs, medicine, water, climate regulation and energy to more than one billion people (IUCN, 2011).Since the existence of man, forests are vital for sustaining development and human wellbeing globally; forests provide livelihood for rural and urban dwellers through the provision of food, shelter, income, other basic necessities of life and developmental services such as wind and erosion control, watershed management, climate change mitigation and carbon sequestration (Ajala et al.,
2019). Most rural and urban people in Africa, Asia and Latin America still rely on trees and woody vegetation to meet their basic energy needs (Madame, 2007). According to Latif et al., (2002), forest resources contribute directly up to $80 \%$ of the livelihood of rural people living in extreme poverty. Nigeria has an estimated population of 150 million (NPC 2006) and an annual growth rate of $2.9 \%$. A larger percentage of the population live in rural areas around forests, where its resources are seen as a means of sustaining livelihoods through domestic energy needs and income generation (Sambo, 2008). Fuel wood, being the cheapest source of energy was sourced from the forests, and this had serious negative effects on the environment. Nnamuchi (2011) stated that $75 \%$ of women sourced their fuel wood from forests around rural settlements because no money was paid for it and it remained the most utilized energy source.

The objective of this review is to reconcile between forest sustainability and economic development.

Fuel wood Consumption in Nigeria: Aju and Uwalaka (2010) observed that fuel wood is the primary source of energy accounting for over $90 \%$ of the total energy used for domestic purposes in Nigeria (Table 1). Nigeria's fuel wood consumption is about 80 million $\mathrm{m}^{3}$, indicating that biomass fuel is the commonest source of household energy in Nigeria (Olumide Ojo, 2019). Fuel wood collection in the country has become a profitable enterprise without any effective control by the government, leading to widespread deforestation (Olori, 2008). Makame (2007) argues that in Africa the pressure on forest resources has increased since the oil shocks of the 1970s. This is mainly because many poor urban dwellers previously using kerosene for cooking have reverted to fuel wood. Between 1991 and 1994, the price of kerosene and cooking gas rose by about $900 \%$ (Momoh and Soaga, 1999). Today it has risen by more than $1000 \%$. UNDP estimates in Olusegun (2009) showed the marginal difference between Nigeria's consumption of fuel wood compared with South Africa and Thailand (Table2). Alternatives and substitutes to fuel wood are often too scarce, expensive and yet to be commercially viable in Nigeria, resulting in the use of any available biomass including crop residue, tree roots, twigs and herbs, leading to serious environmental degradation and hazards (Ampitan and Oyerinde, 2015). Several studies have linked fuel wood utilization with poverty (Table 3). Yahaya (2002) stated that the poorer a country is, the greater its dependence on fuel wood. The United Nations Centre for human settlements also stated that despite the availability of modern energy sources to some city dwellers, the majority of the immigrants cannot afford them, wood still remains their fuel; but instead of collecting it from dead trees, 
branches and twigs, they now buy it from vendors (Habitat-UNCHS, 1990). Extensive use of forests had exposed the most vulnerable segment of the communities, the aged, the poor, women and children, to malnutrition and reduced income, as traditionally their livelihoods partly depends on forest products (FAO, 2009).

Table 1: Fuel wood Consumption Compared with Other Fuel Alternatives in Nigeria

\begin{tabular}{lllll}
\hline Fuel Type & $\begin{array}{l}\text { Annual consumption } \\
\text { of energy (tons/year) }\end{array}$ & $\begin{array}{l}\text { Cons of energy } \\
\text { unit (toe) }\end{array}$ & $\begin{array}{l}\text { Percentage } \\
\text { consumption }\end{array}$ & $\begin{array}{l}\text { Consumption } \\
\text { per capita }\end{array}$ \\
\hline Fuel wood & $43,300,000$ & $16.454^{*} 10^{6}$ & 92.2 & 461.18 \\
Household kerosene & $1,266,370$ & $1.304 * 10^{6}$ & 7.3 & 13.18 \\
LNG & 66,046 & $0.070^{*} 10^{6}$ & 0.4 & 0.79 \\
Coal & 18,100 & $0.013^{*} 10^{6}$ & 0.1 & 0.19 \\
\hline \multicolumn{4}{c}{ Source: Energy Comm of Nigeria $(E C N)$ in David-Sarogoro (2019) toe= tones oil equivalent }
\end{tabular}

Table 2: Fuel Wood Consumption in Nigeria Compared with South Africa and Thailand

\begin{tabular}{llll}
\hline $\begin{array}{l}\text { Country } \\
\begin{array}{l}\text { Fuel wood } \\
\text { consumption }\end{array}\end{array}$ & $\begin{array}{l}\text { Nigeria } \\
262.783 \mathrm{mt}\end{array}$ & $\begin{array}{l}\text { South Africa } \\
7,210 \mathrm{t}\end{array}$ & $\begin{array}{l}\text { Thailand } \\
35,313 \mathrm{t}\end{array}$ \\
\hline \multicolumn{3}{l}{ Source: Olusegun (2009). } & mt $=$ metric tons, $t=$ tones
\end{tabular}

\begin{tabular}{lll}
\multicolumn{3}{c}{ Table 3: Poverty Rate and Percentage of Wood as fuel Source by Geopolitical Zones } \\
\hline Regions & Poverty rate & Percent of Wood as Fuel Source \\
North East & 72.2 & 95.9 \\
North West & 71.2 & 95.3 \\
North Central & 67.2 & 86.4 \\
South West & 43.0 & 54.9 \\
South East & 26.7 & 78.0 \\
South South & 35.1 & 72.7 \\
\hline \multicolumn{3}{c}{ Source: NBS (2007) in Zaku et al, (2013) }
\end{tabular}

According to Ladipo (2010) the forest which was once regarded as an inexhaustible resource may become exhaustible and extinct if unsustainable exploitation is not reversed. This human pressure on the land, due to rapid population explosion has resulted in large scale desertification (Anon 2004), particularly in the rural areas from where these fuel woods were harvested, with the rate of harvest and utilization higher than its natural regeneration or replenishment. Ampitan and Oyerinde (2015) reported a survey of forest resources held between 1996 and 1998, which revealed that Nigeria's forest cover decreased by over $20 \%$ over the preceding 18 years. A survey by Adeyoju (2001), revealed that the forest estate which covered about
$10 \%$ of the country's land area in 1976 had decreased to less than 6\%. FAO reported that, between 1990 and 2010 , Nigeria lost an average of 409,650 ha or $2.38 \%$ of forests per year (tables 4 and 5); indicating a loss of $8,193,000$ ha or $47.5 \%$ of their forest covers within the 10-year intervals (Butler, 2019). In addition, between 2000 and 2005, Nigeria lost $35.7 \%$ of its forest cover, or around 6,145,000 hectares (Babanyara and Saleh, 2010). Reports from Olori (2008) and Ebe (2014) indicated that fuel wood harvesting is causing the loss of an estimated $4 \mathrm{~km}^{2}$ of useful land every year, in addition to exposing the soil to erosion, drought and desertification in central and northern parts of the country.

Table 4: Trends in Nigeria's Total Forest Cover between 1990 and 2010
\begin{tabular}{cllll} 
Year & 1990 & 2000 & 2005 & 2010 \\
Forest Cover (1000ha) & 17234 & 13137 & 11089 & 9041 \\
\hline
\end{tabular}

Table 5: Annual Change Rate (\%) (Negative values represent deforestation)
\begin{tabular}{clll} 
Year & $1990-2000$ & $2000-2005$ & $2005-2010$ \\
Change Rate & -2.68 & -3.33 & -4.00 \\
\hline
\end{tabular}

Nigerian Forest Reserves: FAO recommends that every country should have forest covering at least 25 $\%$ of its total land area (FAO, 2010a); Nigeria has only $10 \%$ of its land area covered by forest and therefore does not meet this recommendation. For that reason, Nigeria is categorized among the countries referred to as low forest cover countries (LFCCs) (FAO, 2003 and FAO, 2010a). Furthermore, even within the $10 \%$ of land under forest, studies have shown that only about $1.3 \%$ of the country's total land area $(12,114$ kilometer square) is considered undisturbed forest cover (FAO, 2003). This is an indication of how extensively the vegetation cover is utilized. Forest reserves were established by the federal government, targeting $25 \%$ of Nigeria's total forest area, in order to conserve its products and biodiversity (Martin, 2010), secure other 
environmental services and contribute to local livelihood improvement (Shackleton et al, 2007). Hence, forest reserves, game reserves, national parks and wildlife sanctuaries were established. These reserves are located in areas where rural dwellers reside in enclaves and communities, thereby leading to their engagement in various socioeconomic activities such as hunting, herbs and fuel wood collection, to sustain their livelihoods. This is because forest reserves were seen as major sources of poverty alleviation, especially by the rural people. Otabor (2017) observed that de reservation became the gateway to invasion of some forest reserves, resulting in their annihilation. Salako et al., (2019) observed that forest land under reservation is like a waste of resources to farmers in some forest reserves, due to their lack of education and exposure.

Case Study: Changes in Kano State Forest Reserves, between 1966 and 2015: Contrary to the objectives of forest reservation, about $65 \%$ of Nigeria's 560 species of trees are now faced with extinction, while many others are at different stages of risk of extinction. Presently, most of these reserves have almost been reduced into mere farmlands and estates. Table 6 showed the extent of changes of some forest reserves, in Nigeria, using Kano State in Northwestern Nigeria as case study

Table 6: Kano state forest reserves and their areal extent

\begin{tabular}{llll}
\hline Forest Reserve/Period & $1966(\mathrm{Ha})$ & $2015(\mathrm{Ha})$ & $\%$ Change \\
\hline Matan fada & 1882 & 102.98 & 53 \\
Duduru gaya & 6416 & 1950.28 & 60 \\
Dansashiya & 6903 & 6871.32 & 0.6 \\
Rurum & 3617 & 2334.72 & 34.45 \\
Falgore & 101594.06 & 92934.78 & 8.52 \\
\hline \multicolumn{4}{c}{ Source: Idris et al $(2018)$}
\end{tabular}

Studies by Idris et al.,(2018) on changes in some forest reserves in Kano State (Table 6) revealed that the major factors responsible for undesirable changes in the forest reserves includes fuel wood collection for cooking and livelihood sustenance, hunting and farming activities; triggered by illiteracy and unemployment. In Rurum reserve, excessive felling of trees for fire wood and clearing for farmlands has completely changed the reserve from a very thick forest, to farmland area. In Matan fada reserve, the observed changes occurred as a result of weak management practices, as tree felling is allowed in the area. At Duddurun gaya reserve, the management practice is taken more seriously, as the officials prohibit tree felling, however the locals still cut down trees for domestic use and livelihood supports (Idris et al., 2018). The report indicated that fuel wood business is the main source of livelihood during the dry season, until the recent development of irrigation scheme in the area, which diverted their attention towards irrigation agriculture during the dry season. The tree species common to the reserve hardly regenerate after cutting, leading to replacement of indigenous species with Azadirachta indica, which is fast growing and extensively used for fire wood. Residents near Falgore reserve were scared by criminals hiding inside the forests. But, more importantly, the reserve is under the care of Kano State Zoo and Wildlife Management Agency (Idris et al., 2018). Settlers around Dansoshiya Reserve, especially the herdsmen, partly contributed in the protection of the Forest Reserve.
Forest Plantations: Forest plantations were established in Nigeria with the initial aim of stimulating natural forests through planting mixtures of many indigenous tree species (Onyekwelu, 2001; Oyewale et al., 2019). This started in Nigeria with the establishment of small-scale plantations at Olokemeji, Mamu and Onigambari forest reserves in Southern Nigeria (Oyewale et al., 2019). Many forest plantations in Nigeria failed to achieve management objectives because of inadequate planning and assessment from the onset, and ineffective management. In developing countries like Nigeria, relatively few forests are formerly managed, unlike in advanced countries, much timber production in Nigeria still comes from natural forests (Oyewale et al., 2019). Investment in industrial plantation establishment is not given much attention in Nigeria, mainly, because of the long gestation period involved.

\section{THE WAY FORWARD}

Awareness and Education as motivating factors: Illiteracy and lack of awareness and prompt information about the environment among rural dwellers, were identified as contributing factors to deforestation and other unsustainable practices (Olorunfemi, 2010; Ajayi, 2013; Khaine and Woo, 2014 and Badamasi, 2014). Forestry and environmental education are highly essential at all levels; locally and nationally, formally and informally. The government has a lot to contribute through orientation, certification for knowledge acquired in sustainable forest management, incentives for compliance with sustainable standards; and local 
empowerment through the provision of grants, basic amenities and alternative sources of income.

Effective policies and legislations: Policies and legislations, management and planning are not effective without addressing the needs and rights of the local people (SF Handbook, 1999). This is because local people are among the major stakeholders in effective policy formulations, legislations, management and planning. In addition, the quest for sustenance is a major threat to Nigerian forests. Forests are sustainable when policies are formulated to address the issues of poverty and food security, alternative means and strategies to make the people less dependent on forests for their sustenance. Pressure on forests can only reduce where management adopts a participatory approach. There should be local empowerment through, development of NTFPs and other local industries, marketing channels and benefit sharing. Basic amenities should be provided for the local populace. They should be trained on modern and sustainable methods of using and managing forests, its resources and its environments. The long gestation period involved in forest trees precludes private investment in plantation forestry. By implication, plantations are better established and managed by governments and institutions. The government also plays a major role in establishing and managing plantations of desirable species for fuel wood production, to reduce the pressure on woody forest resources. Afforestation and reforestation programs are very relevant, considering the fact that most plantations and government reserves have been degraded and dereserved beyond expectation. Besides this, the rate of forests exploitation exceeds regeneration.

Social issues: Social issues are the biggest challenge in forest management (SF Handbook, 1999). Social concerns need to be incorporated at all stages: planning, implementation and monitoring. Forest management and organizations are recommended to make a special effort to address social issues. In managing forests, the management is likely to experience problems if it ignores or violates stake holders' rights and local participation. The role of women must be well understood, as they play a major role in forest resources utilization and management.

Private sector involvement: Private investors and NGOs should be motivated to promote and invest in forestry. Forest management has become so crucial that there is need for the establishment of autonomous Ministry of forestry, which is already coming up in some areas, at both state and federal levels. Such ministry should work together with relevant ministries, such as the ministries of agriculture, and environment.

Harnessing Alternative Energy Sources into Domestic Energy Needs: The situation will remain unchanged, until the government and other stakeholders develop alternative sources of fuel to reduce pressure on the existing depleting resources. This starts from the establishment of well-planned and managed fuel wood lot of indigenous multipurpose trees, which will not only supply fuel wood and non-wood forest products, but also serve as sources of income, local empowerment, and feeding for man and livestock. Studies by Babanyara and Saleh (2010) observed and developed viable alternatives to the rapidly depleting wood fuel in Nigeria. Such includes solar energy, water or hydroelectric power, biomass and wind energy.

Conclusion: This review has provided valuable information on Nigeria's fuel wood consumption, its effect on the forests, and the responsible factors, together with suggested mitigation and abatement strategies. There is therefore the need for stakeholders in the forestry sector to plan towards sustainable management through local empowerment and poverty reduction, participatory forestry and provision of alternative sources of fuel for domestic use.

\section{REFERENCES}

Adeyoju, K (2001). Forestry for national development: A critique of the Nigeria situation. Proceedings of $27^{\text {th }}$ Ann Conf. of FAN. Abuja, $17^{\text {th }}$ to $21^{\text {st }}$ September, 2001. Pp 55-68.

Ajala, OO; Adelusi, EA; Alaiye, IO (2019). Sustainable Management and Utilization of Forest Products for Food Security in Africa: The Role of Women. Proc of the $41^{\text {st } F A N ~ C o n f . ~}$ Abuja, $7^{\text {th }}$ to $11^{\text {th }}$ October, 2019. Pp 343-350

Ajayi, OO; Oluwatoyin, O (2013). Nigerias energy policy: Inferences, analysis and legal ethics towards RE development. Energy Policy. 60, 6167.

Aju, PC; Uwalaka, RE (2010). Forest Resources and the Economy of Rural Nigerians. In:HM. Ijeomah; AA. Aiyeloja, (eds.). Practical Issues in Forest and Wildlife Resources Management. Green Canopy Consultants, Choba, Port Harcourt. Pp172-191.

Aju, PC (2014). The role of forestry in agriculture and food security.Am. J. Res. Commun. 2014,

2(6): 109-121. 
Aminu, I (2003). Desertification in Northern Nigeria; which way forward. Daily trust newspaper $27^{\text {th }}$ August 2003. Pp 26.

Ampitan, TA; Oyerinde, OV (2015). Pattern of Domestic Energy Utilization and Its Effect on the Environment in Jos, North central, Nigeria. Res. J. Agr. Env. Sci. 4(9): 432-437

Anon (2004). World Population Data Sheet. Population Reference Bureau,Washington, DC, USA

Anozie, AN; Bakare, AR; Sonibare, JA; Oyebisi, TO (2007). Evaluation of cooking energy cost, efficiency, impact on air pollution and policy in Nigeria. Energy 32 (7): 1283-1290

Babanyara. YY; Saleh. UF (2010). Urbanization and the Choice of Fuel Wood as a source of Energy in Nigeria. J. Hum. Ecol. 31 (1): 19-26

Badamasi, MM (2014). Vegetation and Forestry. In: A.I Tanko and S.B. Momale (eds.). Kano Environment, Society and Development. London and Abuja, Adonis and Abbey Publishers. pp. 4364.

Butler, RA (2019). Nigeria forest information and data. Tropical Rainforests: Deforestation rates tables and charts. Retrieved from https://rainforests.mongabay.com/deforestation/20 00/Nigeria.htm, On 6/3/20

Bzugu, PM; Ibrahim, AA (2011).Participatory community efforts in forestry and Management of Semi-Arid Zone Nigeria. Paper presented at a w/shop org by Cent for Arid Zone Studies at Konduga LG, Borno State.

Census (2006). Report of NPC on the 2006 Census.Popu. Dev. Rev, 33(1): 206-210

David-Sarogoro, N; Timitimi, E; Emerhi, EA (2019). Fuel wood Utilization and Sustainable Management of Forestry Resources: Panacea for Poverty Alleviation. Proc of $41^{\text {st }}$ FAN conf, Abuja, $7^{\text {th }}$ to $11^{\text {th }}$ October, 2019. Pp. 49-55

Ebe, FE (2014). Socio-economic factor influencing theuse of fuel wood in urban areas of Enugu State, Nigeria. IOSR- JBM.16 (II): 147-151.

FAO (2003). Experience of Implementing National Forestry Programmes in Nigeria.Sustainable forest management programmes in African ACP countries.

http://www.fao.org/DOCREP/005/AC918E/AC91 8E04.htm - accessed on 10/01/2010.

FAO (2009). A Foresters guide for community involvement in upland conservation. FAO. Rome. Habitat-UNCHS, 1990. https://digitallibrary.un.org.record.

FAO (2010a). Global Forest Resource Assessment Main Report 2010. Forestry paper, 163. http://foris.fao.org/static/data/fra2010/FRA2010 Report en WEB.pdf-

Gajic, G; Djurdjevic, L; Kostic O; Jaric, S; Mitrovic M; Pavlovic P (2018). Ecological potentials of plants for phytoremediation and eco restoration of fly ash deposit and mine wastes. Front.Environ. Sci. 6:124.

Idris, HA; Ahmad, M; Muhammad, UK; Nuhu, Z (2018). An Examination of Changes in Some Forest reserves of Kano State, Nigeria. FUDMA. J. Sci. 2(4): 221-230.

IUCN (2011). International Union for Conservation of Nature. The national economics research institute (NERI) ministry of planning and investment of Lao PDR. Natural Environmental Research Council, Abbots Ripton, Huntington, UK, pp 327-350.

Khaine, I; Woo, SY (2014). Assessment of the environmental awareness of local people living in and around forests in Myanmar: a case study of Yandashae and Pauk-Kaung Towmnships. Available at www.fdmoecaf.gov.mn

Ladipo, D (2010). The State of Nigerian Forests. http://adreview.org/2010/04/the state of Nigeria'sforests

Latif, A; Shinwari, ZK; Begum, S (2002). Potentials of Market Status of Mushrooms as Non-Timber Forest product in Pakistan. Ethno-Botany Project. WWF-P. Peshawar. Pakistan.

Makame, OM (2007). Adoption of improved stoves and deforestation in Zanzibar. Manag. Environ. Qual. Int. J. 183: 353-365.

Martin, GO (2010). A keynote address delivered at a one-day workshop on Environmental andEnergy Conservation for pollution based and to mark World Environment Day in Benin City, June $4^{\text {th }}$, 2010 . 
Momoh, S; Soaga, J (1999).National Bureau of Statistics (NBS) (2007). Annual abstracts of statistics. National Bureau of statistics, Abuja, Nigeria.

Nnamuchi, O (2011). The Right to Health in Nigeria. Center for Health Bioethics and Human Rights. Retrieved from https://papers.ssm.com/sol3/papers.cfm?abstract_i $\underline{\mathrm{d}=1622874}$

Ogunsanwo, OY; Ajala, OO (2002). Firewood crisisin Lagos: Implication on Sub-Urban andRural Ecosystem Management.Proceedings of the 28th Ann Confof FAN. Pp. 402-408.

Olori, T(2008). Environment - Nigeria: Rich in oil, dependence on firewood. IPS - Inter Press service.

Olorunfemi, $\mathrm{F}(2010)$. Risk communication in climate change and adaptation; Policy issues and challenges for Nigeria. http://iopscience.iop.org/1775-1315.pdf

Olumide OO; Awolala DO (2019). Fuelwood usage and its challenges on the health of women and children in Akoko South-west Local Govt Area of Ondo State. Proceedings of $41^{\text {st }}$ FAN Conf.Abuja. $7^{\text {th }}$ to $14^{\text {th }}$ October, 2019. Pp 280-286.

Olusegun, KA (2009). Threats to Nigerian environment: A call for positive Action. Paper presented at the $7^{\text {th }}$ Chief S.L EDU Memorial lecture held at Ondo townhall. August 13, 2009.

Onyekwelu, JC (2001). Growth Characteristics and Management Scenarios for Plantation Grown Gmelina arboreaand Naucleadiderrichii in southwestern Nigeria. Published Ph. D. Thesis; Hieronymus Publishers, Munich Germany; 201pp.

Otabor, O(2017). Ogba Zoo and Nature Park in throes of death. www.thenationonlineng.net/ogba-zoonature-park-throes-death

Oyewale, OO; Ademola, AA; Ademola, IT (2019). Forest Management and the Challenges of Environmental Sustainability. Proc of $41^{s t} A n n$ Conf of FAN. Abuja. Pp 451-456.

Salako, BA; Bolaji-Olutunji, KA; Agbeja, BO (2019). Assessment of prevailing causes and effect of conflicts between Forestry and Agric land uses in Omo forest reserve Area J4 Ogun State. Proceedings of 41 ${ }^{\text {st }}$ FAN Conf. Abuja. Pp 571-580.
Sambo, AS (2005). Renewable Energy for Rural Development: The Nigerian Perspective. ISESCO, Sci. Tech. Vision. 1: $12-22$.

Sambo, AS (2008). Renewable energy options for the environment and sustainable development in Nigeria. Paper presented at the National Workshop on Energy Investment and Private Sector Participation at the Petroleum Training Institute, Efuruum, Delta State, Nigeria.

Sambo, AS (2009). The Challenges of Sustainable Energy Development in Nigeria. Paper Presented at the Nigerian Society of Engineers Forum, 2nd April, 2009 at Shehu Yar'Adua Centre, Abuja.

Shackleton, CMS; Shakleton, SE; Buiten, E; Bird, $\mathrm{N}(2007)$. The importance of dry wood lands and forests in rural livelihoods and poverty alleviation in South Africa. Forest. Policy. Econ. 9: 558-577.

The Sustainable Forestry Handbook (1999). A practical guide for tropical forest managers on implementing new standards. Earthscan Pubs Ltd, London.

UNCCD (2014). Consequences of desertification. United nations convention to combat desertification. Fact Sheet 3. www.uncd.int/publicinfo/factsheet

Yahaya, SB (2002). The Development and adoption of local alternative sources of energy against fuel wood. A paper presented at a two-day w/shp on Agroforestry mgt,for sust agric production; Manpower devpt centre. Office of the Head of service, Kano State. pp. 129-130.

Zaku, SG; Kabir, A; Tukur, AA; Jimento, LG (2013). Wood fuel consumption in Nigeria and the energy ladder: A review of fuel wood use in Kaduna State. J. Pet.Technol. Altern. Fuels. 4(5): 85-89 